\title{
Perception and knowledge about HIV/AIDS among Nepalese adolescent
}

\author{
BA Dhungel'1, N Shreshtha1, K U-Dhungel1, 2 \\ KIST Medical College, Lalitpur, Nepal \\ Think Tank foundation, Jorpati, Kathmandu, Nepal
}

1Think Tank Foundation, Jorpati, Nepal

${ }^{2}$ Associate Professor, Department of Physiology, Janaki Medical College, Nepal

\begin{abstract}
Background and Objectives: Nepal is confronted with increasing incidence of HIV among adolescents. There is need to ensure, these people have correct knowledge for HIV prevention. Hence, this study was carried out to assess the perception and knowledge of adolescents regarding HIV/AIDS and to identify the areas of misconception that might serve as an important target of educational intervention.
\end{abstract}

Methodology: A self designed questionnaire regarding knowledge and perception about HIV/AIDS was distributed to the students of secondary school who attended the heath assessment program organized by Kist Medical College. Submitted questionnaires were analyzed and tabulated to find out the existing knowledge and attitude of the participants.

Results: Knowledge regarding HIV/AIDS was satisfactory. Seventy-nine percentage of female and $64 \%$ male agreed to care for HIV/AIDS patients. However there were still misconceptions about transmission. Sixty-two percentages thought that contraceptive pills prevent HIV transmission. Thirty two percent thought that mosquito can transmit HIV, $21 \%$ replied that sharing of utensils, and towels etc can transmit HIV. Forty five percentage of the participants thought that someone who looks healthy cannot transmit HIV.

Conclusion: Perception regarding HIV/AIDS was satisfactory. Some areas of misconception was detected which can be overcome with proper educational interventions.

Key words: HIV, AIDS, knowledge, adolescents

\section{INTRODUCTION}

HIV/AIDS is a burning crisis worldwide. When it hits a least developed nation like Nepal, management of HIV/AIDS becomes even more difficult [1]. The first case of HIV was detected in 1988 AD in Nepal and within two decades there are about 100,000 people living with HIV [2]. It is very likely that the actual number of cases is many times higher 
than the documented cases [3]. Nepal has moved from low prevalence status to concentrated epidemics with prevalence of $17.3 \%$ and $68 \%$ among female sex workers and intravenous drug users respectively [4]. There is evidence of explosive increase in the number of infection since 1996. AIDS is a leading cause of death in 15-49 years age group, which means 100,000-200,000 young adults are likely to become infected and overall 10,000-15,000 new annual AIDS cases and deaths due to AIDS related illness. This will further increase the poverty, vulnerability and overall negative impact on socioeconomic development of the nation [4]. The country's vulnerability to HIV/AIDS is exacerbated by geographic and ethnic diversity. Its poverty, inequality, underdevelopment, civil conflict, political instability, migration abroad for work and varied level of knowledge about HIV transmission among most at risk group and young population.

Nepal is confronted with increasing incidence of HIV among young adults [5]. Injecting drug users are one of the most susceptible groups to acquire HIV. Adolescent are the identified vulnerable group for intravenous drug users (IVDUs). Prevention intervention coverage is low for people under 25years of age. There is need to ensure that $80 \%$ of young people who are the most at risk are reached with correct information and acquire appropriate skills and knowledge for HIV prevention [6].

Nepal has inadequate infrastructure such as clinics, district hospitals and distribution units needed to provide antiretroviral treatment for people living with HIV [4]. This further signifies the need and importance of prevention activities. Prevention is also much cheaper to implement than curative means especially in a developing country like Nepal.

Although adolescents in Kathmandu have some information regarding HIV/AIDS, there are still some misconceptions and many have not encountered people with HIV. This situation may lead to unnecessary fear, ignorance and uncertainty among adolescents. They may also develop negative attitude towards HIV positive people due to over emphasis of the dreadfulness of HIV infection. It may produce irrational behavior in adolescents toward those with HIV/AIDS. In Nepal, there are limited school education program on sexually transmitted disease including HIV/AIDS.

Hence, this study was planned and carried out to assess the perception, knowledge and awareness of adolescents regarding HIV/AIDS and to identify the areas of confusion that might serve as an important target of educational intervention.

\section{MATERIAL AND METHODS}

A self designed questionnaire was prepared and distributed to the students of secondary school who attended the heath assessment program organized by Kist Medical College.

The participants were explained the objectives of the study and invited to participate. Written informed consent was obtained from the school authority and participating students. One hundred and seventeen students filled up the form and returned. (Response rate 98\%).

Questionnaires were administered after explaining the nature and anonymity of the survey and assuring the confidentiality of the personal responses. Participants sat apart and were asked not to communicate with 
each other while responding to the questionnaire so as to obtain honest response.

\section{RESULTS}

One hundred and seventeen ( $\mathrm{N}=117)$ participants filled out the questionnaire and returned back to the investigator. Out of which, 74 (63\%) were male and 43 (37\%) were female (Response rate $98 \%$ ).

The age of the participants ranged from 1117 years. Mean age of the participants was $13.2 \pm$ 2.2. Knowledge regarding transmission of HIV/AIDS was found fairly well among majority of the participants however, some misconceptions did exist (Table $1 \& 2$ ).

Table 3 and Table 4 show the attitude and perceptions of the respondents on different aspects of HIV and AIDS. Most of the respondents seems to have good perception and have positive attitude.

Majority of the students were not very comfortable in asking queries about HIV/AIDS to their parents, they identified mass media as the most common source of information. Physical relation was stated as the most common mode of transmission of HIV (Figure 1-3 respectively).

\section{Table1: General knowledge regarding HIV/AIDS}

\begin{tabular}{|c|c|c|c|c|}
\hline SN & Questions & $\begin{array}{c}\text { Right answers } \\
\text { in total }(\%) \\
(\mathrm{N} 1=117)\end{array}$ & $\begin{array}{c}\text { Right answers } \\
\text { from Female in } \\
\% \\
(\mathrm{~N} 2=43)\end{array}$ & $\begin{array}{c}\text { Right answers } \\
\text { from Male in } \\
\% \\
(\mathrm{~N} 3=74)\end{array}$ \\
\hline 1 & $\begin{array}{l}\text { Do you think HIV/AIDS is one of the major } \\
\text { problems in Nepal? }\end{array}$ & 73 & 72 & 74 \\
\hline 2 & $\begin{array}{l}\text { Do you think HIV/AIDS is a life threatening } \\
\text { disease? }\end{array}$ & 91 & 98 & 86 \\
\hline 3 & $\begin{array}{l}\text { Can the use of condoms prevent people from } \\
\text { getting HIV/AIDS? }\end{array}$ & 91 & 93 & 89 \\
\hline 4 & $\begin{array}{c}\text { Does the use of contraceptive pill protect } \\
\text { women from getting HIV/AIDS? }\end{array}$ & 38 & 33 & 41 \\
\hline 5 & $\begin{array}{c}\text { Do you know what sexually transmitted } \\
\text { diseases are? }\end{array}$ & 93 & 93 & 93 \\
\hline 6 & Is HIV/AIDS a sexually transmitted disease? & 96 & 98 & 95 \\
\hline 7 & $\begin{array}{l}\text { HIV infected people should never donate } \\
\text { blood. }\end{array}$ & 100 & 100 & 100 \\
\hline 8 & $\begin{array}{l}\text { There is no test to detect whether a person } \\
\text { has HIV/AIDS. }\end{array}$ & 95 & 98 & 93 \\
\hline
\end{tabular}

N1, Total respondents; N2, Male respondents; N3, Female respondents 
Table 2: Knowledge regarding transmission HIV/AIDS

\begin{tabular}{|c|c|c|c|c|}
\hline SN & Questions & $\begin{array}{c}\text { Right answers } \\
\text { in total }(\%) \\
(\mathrm{N}=117)\end{array}$ & $\begin{array}{l}\text { Right answers } \\
\text { from Female } \\
\text { in } \%(\mathrm{~N}=43)\end{array}$ & $\begin{array}{c}\text { Right answers } \\
\text { from Male in } \\
\%(\mathrm{~N}=74)\end{array}$ \\
\hline 1 & $\begin{array}{c}\text { Can a person get HIV/AIDS by sharing } \\
\text { needle/syringe with someone with HIV/AIDS? }\end{array}$ & 97 & 96 & 99 \\
\hline 2 & $\begin{array}{c}\text { Can a woman get HIV/AIDS from her HIV } \\
\text { infected husband? }\end{array}$ & 96 & 100 & 93 \\
\hline 3 & $\begin{array}{l}\text { If someone with HIV/AIDS coughs/sneezes } \\
\text { near other people, could they get HIV virus? }\end{array}$ & 68 & 46 & 74 \\
\hline 4 & Can a person get HIV/AIDS from mosquito? & 63 & 65 & 62 \\
\hline 5 & $\begin{array}{c}\text { Can a person get HIV/AIDS by sharing utensils, } \\
\text { towels with HIV infected people }\end{array}$ & 79 & 77 & 81 \\
\hline 6 & $\begin{array}{l}\text { Can a person get HIV/AIDS by sharing toilets; } \\
\text { swimming pool with HIV infected people? }\end{array}$ & 80 & 74 & 84 \\
\hline 7 & $\begin{array}{l}\text { If a pregnant woman has HIV/AIDS, could her } \\
\text { baby get HIV? }\end{array}$ & 97 & 100 & 96 \\
\hline 8 & $\begin{array}{l}\text { Can someone who looks very healthy pass on } \\
\text { HIV to other people? }\end{array}$ & 55 & 42 & 62 \\
\hline
\end{tabular}

Table 3: Attitude towards people living with HIV/AIDS

\begin{tabular}{||c|c|c|c|c|c|c|c|}
\hline SN & Questions & \multicolumn{2}{c|}{ Agree \% } & \multicolumn{2}{c|}{ Disagree \% } & \multicolumn{2}{c|}{ Not sure \% } \\
\cline { 3 - 8 } & Female & Male & Female & Male & Female & Male \\
\hline 1 & $\begin{array}{c}\text { I would stop being friend with someone if that } \\
\text { person got HIV/AIDS }\end{array}$ & 5 & 5 & 81 & 77 & 14 & 18 \\
\hline 2 & $\begin{array}{c}\text { Young people with HIV/AIDS should be allowed } \\
\text { to study in school. }\end{array}$ & 91 & 81 & 2 & 9 & 7 & 10 \\
\hline 3 & $\begin{array}{c}\text { People who have HIV/AIDS should be allowed } \\
\text { to work with other people. }\end{array}$ & 86 & 88 & 7 & 11 & 7 & 1 \\
\hline 4 & $\begin{array}{c}\text { If given chance I would like to care for } \\
\text { HIV/AIDS patients. }\end{array}$ & 79 & 64 & 5 & 5 & 16 & 31 \\
\hline 5 & $\begin{array}{c}\text { People who have HIV/AIDS are only to blame } \\
\text { themselves? }\end{array}$ & 28 & 21 & 58 & 53 & 14 & 26 \\
\hline
\end{tabular}


Table 4: Perception regarding HIV/AIDS

\begin{tabular}{|c|c|c|c|c|c|}
\hline \multirow{2}{*}{ SN } & Questions & \multicolumn{2}{c|}{ True \% } & \multicolumn{2}{c|}{ False \% } \\
\cline { 2 - 5 } & & Female & Male & Female & Male \\
\hline 1 & HIV problem is not as bad as people think. & 60 & 58 & 40 & 42 \\
\hline 2 & I keep away from people who I think may have HIV. & 9 & 24 & 91 & 76 \\
\hline 3 & I am too young to get HIV. & 37 & 27 & 63 & 73 \\
\hline 4 & People from my culture don't get HIV & 7 & 15 & 93 & 85 \\
\hline 5 & People should be careful about choosing life partner. & 100 & 100 & 0 & 0 \\
\hline
\end{tabular}

Fig. 1: Are you comfortable in asking your queries about HIV to your parents?

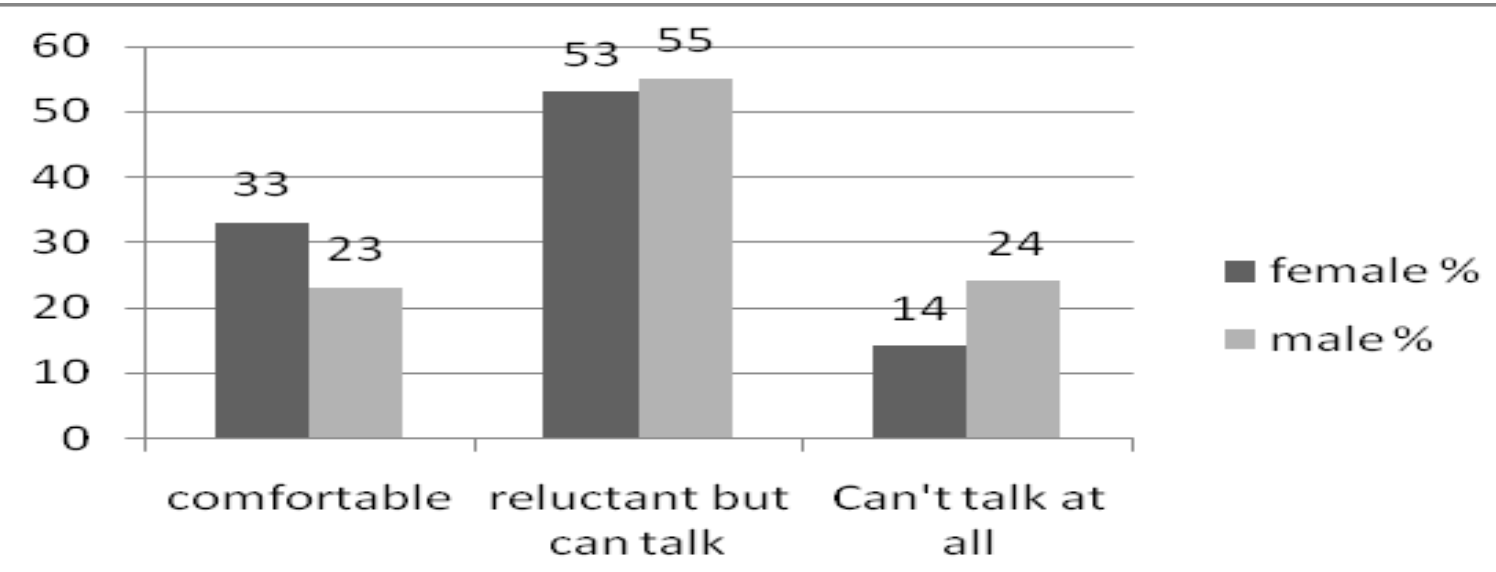

Fig.2: source of information for HIV/AIDS

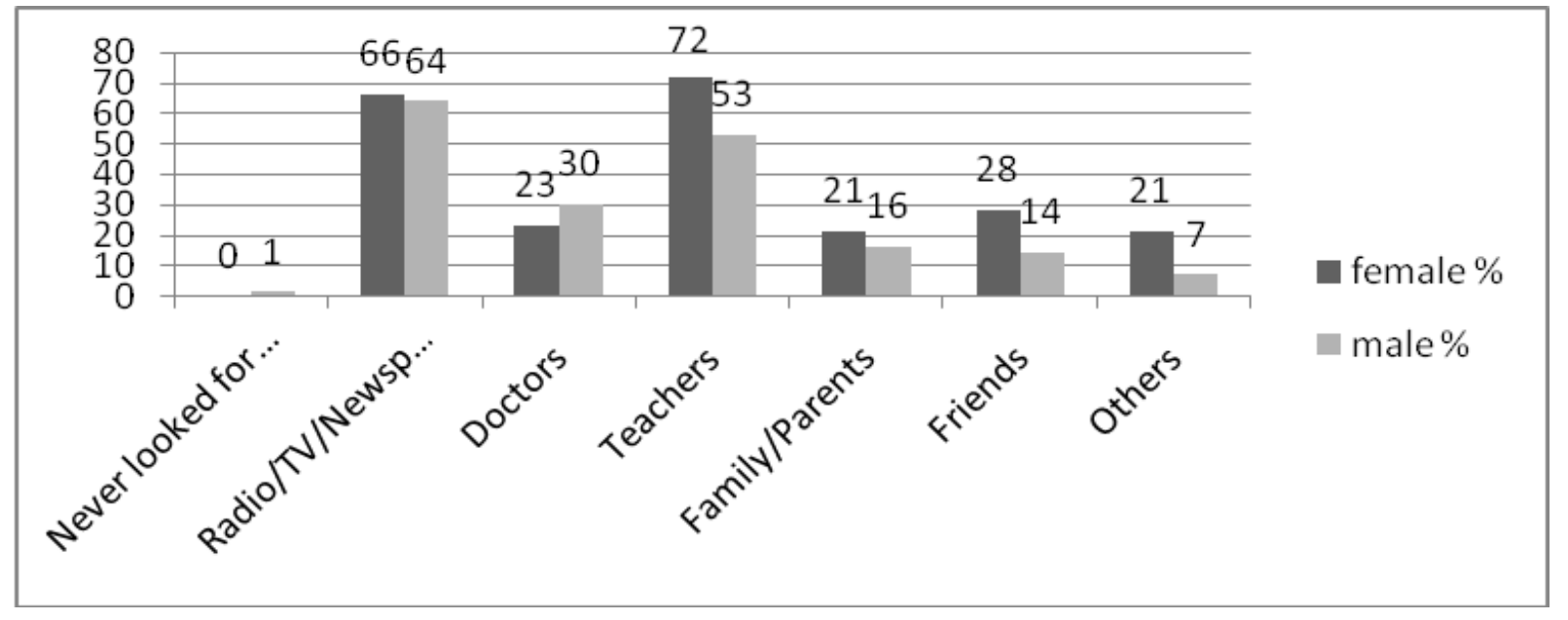


Fig. 3: What is the main/most common mode of transmission of HIV?

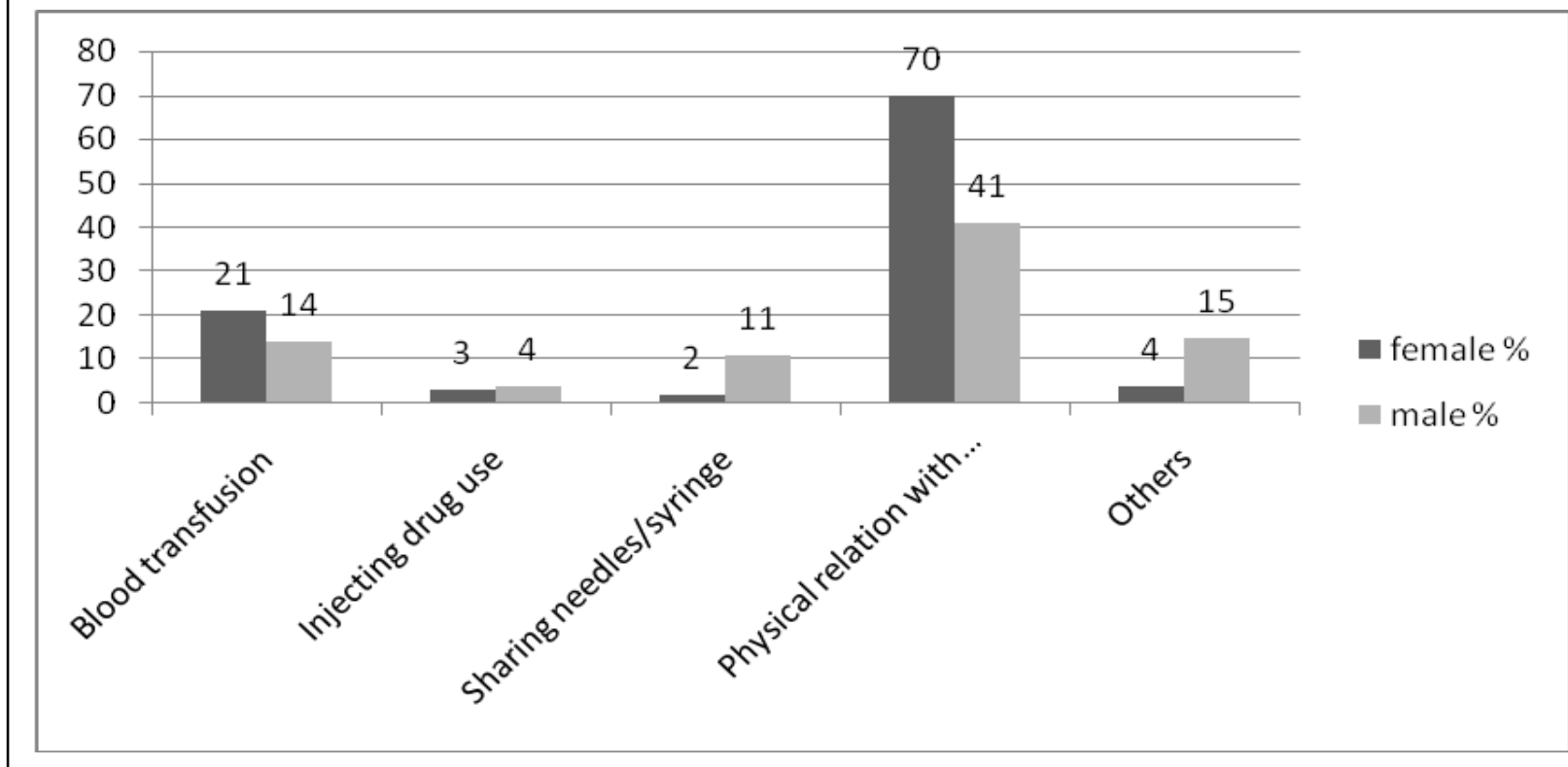

\section{DISCUSSION}

Mass media has become the most easily accessible tool to disseminate information. The majority of students got their information on HIV/AIDS from mass media and teachers. Female participants were more comfortable in asking queries to teachers than male participants (Figure: 2). Majority of the students were reluctant but could talk about HIV/AIDs with their parents. This suggests the importance of involving parents, teachers and students in AIDS education program. The motivation of interest in parents and teachers concerning HIV/AIDS may help them to educate themselves and their children/students [7] and may help to overcome unnecessary fear and discrimination against people living with HIV/AIDS. Ninety one percentage students acknowledge the severity of HIV/AIDS as life threatening disease. The contribution of mass media in raising AIDS awareness could be well appreciated.
Most students demonstrate good knowledge of HIV/AIDS. This is consistent with the study done by Singh et al in adolescents of Chitwan district, Nepal [8]. However, misconceptions do exist. $32 \%$ of the students identified mosquito bite as possible route of transmission of HIV. Similarly, 21\% thought that sharing utensil, towel, toilet and swimming pool with HIV positive people can cause transmission of HIV (Table. 1). Such misunderstanding tends to produce prejudices against those having HIV/AIDS.

One of the striking finding of this study was that $62 \%$ students thought, the use of contraceptive pills could help prevent HIV/AIDS. Both female and male students were found to have poor knowledge regarding the use of contraceptives and HIV/AIDS. It has to be rectified which further signifies the importance and need of awareness programs. $45 \%$ of the participants thought that someone who looks healthy cannot transmit HIV. This type of misconception can cause very serious 
problem especially in a scenario like ours where lifestyle is shifting from conservative to more free western style. In a study by Germain et al, the calculated residual risk per million blood donations attributable to window period (period between infection and detection of the virus by test) transmission was found to be $0.2 \%$ [9]. Though the figure is small, still precaution needs to be taken in choosing partners for marriage and blood donors.

The students in this study demonstrated considerable consistency between knowledge and attitude. $79 \%$ female and $64 \%$ male agreed that they would like to care for HIV/AIDS patients. In general, female had softer attitude towards HIV/AIDS patients. A small percentage did have negative attitude (Table 2, 2.1) which could be lowered with educational intervention. A study from Norway reported that the longer the educational plans, the lower were negative attitudes [10]. Good knowledge is associated with positive attitude towards HIV/AIDS. A report from Philippines demonstrated a positive change in attitude among nurses and midwives after receiving accurate information and interactive role-play concerning HIV/AIDS [11].

Most of the students in this study have never met HIV positive persons. Therefore, in addition to AIDS health education in schools, efforts to invite people living with HIV to come to college and talk to students about their experience regarding HIV will be very beneficial to understand AIDS more deeply. Reports from Australia and Guam have indicated that positive changes in students' perception/behavior toward those having HIV/AIDS were noted after talks by HIV sero positive people to colleges' students [12].
Similarly, a study of Filipino high school students found a positive association between good knowledge concerning AIDS and tolerance of people with HIV/AIDS [13]. A higher level of knowledge and more positive attitudes among Japanese nursing students have also been reported by Okada et al [14].

\section{CONCLUSION}

In this study there are a small percentage of people with negative attitude towards HIV positives. Majority have good knowledge regarding HIV/AIDS, however some misconceptions were there. These misconceptions can be rectified by effective educational interventions which will also help to build positive attitude towards people living with HIV/AIDS.

\section{ACKNOWLEDGEMENTS}

Authors wish to acknowledge the support of Think Tank foundation, Jorpati and Sakura Nepal for their support in carrying out this project.

\section{REFERENCES}

1. Dhungel BA, Dhungel KU, Easow JM, Singh YI. Opportunistic infection among HIV seropositive patients in Manipal Teaching Hospital, Pokhara, Nepal. Kathmandu University Med J 2008; 6: 33539.

2. Rodrigo C, Rajapakse S. Current status of HIV/AIDS in South Asia. J of Global Inf Dz 2009;1:93-101.

3. United Nations General Assembly (UNGASS); National report; Nepal2005

4. Acharya B, Dhungel KU, Easow JM, Singh Y .Study of risk factors for human immunodeficiency virus transmission among seropositive cases. I, J of Ins of Medicince, 2006; 28: 39-41.

5. Joshi DR, Khatri DB, Rosyara KP, Malla B. Do behavioral patterns of university students of Nepal make them vulnerable to HIV/AIDS. J of Inst of Med2007; 29:13-17. 
6. Unicef, Adolescent HIV \& AIDS prevention. http://www.unicef.org/nepal/5522_Adolescent_HI V and_AIDS_prevention.htm. accessed on 05th \anuary2010.

7. Maswanya ES, Moji K, Horiguchi I, Nagata K, Aoyag $\mathrm{K}$, Hona S, Takemoto T. Knowledge, risk and perception of AIDS \& reported sexual behavior among students in secondary schools and colleges in Tanzania. Health Education Research1999; 14: 5-11

8. Singh SK, Manandhar N, Prasai M, Patowary S, Krishna G. An awareness study of HIV/AIDS among adolescent students of Chitwan district, Nepal. J of Inst of Med 2005;27:17-20.

9. Germain M, Gelinas S, Delage G. Estimates of risk of window period transmission of blood-borne viral disease in Quebec. Canadian Medical Association Journal, 2004;70:1077-78.

10. Rise J. Adolescent knowledge about HIV/AIDS. Journal of Health Psychology1997; 2: 57-67.

11. Fernandez SP, Diaz SP. Attitudes of Nursing and Auxiliary staff towards HIV infected and AIDS in Spain. Journal of the association of nurses in AIDS care1997; 5:62-69.

12. Paxton. Utilising HIV positive spearkers- a powerful tool. International Conference AIDS. 2000 Jul 9-14;13: abstract no: Tube D3574.

13. Aplasca MR, Siegel D, Mandel JS, Santana-Arcioga RT, Paul J, Hudes ES et al. AIDS (London, England) 1995 July; 9 Suppl.

14. Okada K, Kodera R, Yasuda N, Ohara $H$. Relationship of AIDS related knowledge with attitude of nursing students towards HIV infected persons. Nippon Koshu Eisei zasshi Jun 1994; 41(6):538-48. 